\title{
Validation of Communication Activities of Daily Living- Second Edition (CADL-2) on Arab Aphasics: Controlled Study
}

\author{
Sadeq Ali Saad Al Yaari (Corresponding author) \\ Independent Researcher, Dept. of English, College of Arts, King Saud University (KSU) \\ Riyadh, Kingdom of Saudi Arabia \\ E-mail: prof.sadeq@gmail.com
}

\begin{abstract}
Nassr Almaflehi
A professor of Statistics, College of Applied Medical Sciences, King Saud University (KSU)

Riyadh, Kingdom of Saudi Arabia

E-mail: nassr_almaflehi@hotmail.com
\end{abstract}

Received: October 28, 2013 Accepted: November 10, 2013 Published: December 12, 2013

doi:10.5296/jsel.v1i2.4738 URL: http://dx.doi.org/10.5296/jsel.v1i2.4738

\begin{abstract}
Background: While language-related tests including communication activities of daily living-second edition (CADL-2) test showed that alike were able to test language-related functional and communication skills, psychoneurolinguists and speech language pathologists/ Therapists (SLP/Ts)'s responses varied between accepting or rejecting the results of this test.

Purpose: Previous studies suggest that results of CADL-2 do not differ with both gender aphasics suffering from different language impairments. Thus, the current study tested the validity and reliability of this test among Arab aphasics.

Design: CADL-2 Pre-and-posttest was administered twice in three weeks to test the communication activities of daily living of 100 aphasic participants of both sexes.

Settings: Al Khars hospital in Al Ahsa'a, Kingdom of Saudi Arabia (KSA).

Participants: A total of 100 (50 men and 50 women) gender aphasic participants who suffer from different language deficits were enrolled in this experimental study.
\end{abstract}


Procedures: Having the English version of CADL-2 translated into Arabic and standardized by three Arabic language experts, the first CADL-2 (Arabic version) test (pre-test) was administered to the participants under investigation in the first week and after two weeks (exactly at the end of the third week)., the second CADL-2 (posttest) was administered. Both tests were conducted in natural environment without any influence from testers or participants' families.

Interventions: Results including gender-specific differences were qualitatively and statistically analyzed and comparisons were made to illustrate these results.

Main outcomes \& Results: The analysis results of each aphasic participant show that no significant differences were observed in CADL-2 pre-and-posttest. The test could test what it was supposed to test. Moreover, the results of the participants' pre-and-posttest are similar with mean of percentile in the pre-and-posttest surging $29.5 \%$ and $28.6 \%$ and Stanine scores surging $3.4 \%$ and $3.32 \%$ for males in comparison to the female aphasic participants who scored $28.16 \%$ and $28.78 \%$ in the percentile and $3.38 \%$ and $3.38 \%$ in the Stanine scores. Taken together, the results demonstrate that the level of aphasics' communication activities is low. Such results prove that the test is also reliable.

Conclusions \& Implications: CADL-2 is considered to be a validated tool for the assessment of Arab aphasic patients of both sexes. These results also provide much needed quantitative data for the diagnosis of language impairments in Arab aphasic patients.

Keywords: CADL-2, language test, Arab aphasics, validity, reliability, psychoneurolinguistics

\section{Introduction Chapter}

\subsection{Introduction}

Increasing number of assessment tools, notably those relating to adults throughout the world have created an urgent need for intensive investigations and strategies that clinicians and speech language Pathologists/ Therapists (SLP/Ts) use to meet the highest standards and criteria of diagnosis. For example, research has shown that stacked-wave-V auditory brainstem response (ABR) requires a masking technique that may not be readily available to the clinician. Moreover, relatively high-level noise is required and may be annoying to the patient requires a masking technique that may not be readily available to the clinician. Since the only alternative choice was tone-bursts assessment tool, there was a need for more research to compare the merits and demerits of the two tools. Philibert, et al., (2003) have undertaken a comparative study between the two assessment tools. The overall objective of the researcher was "to explore a possible alternative approach, particularly one that might be both more accessible to the clinician, regardless of evoked potential test instrument used, and perhaps more acceptable to the patient." (Philibert, et al., 2003:p.2)

Neuropsycholinguistically speaking, aphasia refers to language disorders marked by impairments in language abilities and communication skills, and is associated with cognitive impairment and deficits in adaptive functioning. Evaluative tests have consistently 
demonstrated that aphasics with language impairments have deficits in both language areas and cognitive motor. Attempting to examine the validity and reliability of them, Brogden (2008) undertakes a study on the tests administered for aphasics to identify to what extent these tests could be used to test gender. Cross-sectional design and five dynamic indicators of basic early literacy skills measures have been identified as two valid assessment tools to test oral reading fluency in both sexes (Below, et al., 2010).

Is dysphagia short questionnaire (DSQ) valid or not? Today it is widely believed, among the neuropsycholinguists, SLP/Ts and experts alike, that the questionnaire of the aphasics is linked with better knowledge of aphasia's type (Skeppholm, et al., 2012). Is this notion correct or yet another stereotype? To address this question, the validity of DSQ, as assessed by SLP/Ts, is considered. A new perspective was taken in this research by controlling for age, which is one of the principal psychoneurolinguistic characteristics that interacts with the questionnaire itself, in order to clarify how it affects the diagnosis process. The DSQ was constructed in collaboration with a group of ear-nose-and-throat specialists. In a first validation study, 45 patients with stationary dysphagia for various reasons completed the DSQ twice 2 weeks apart. To evaluate the utility of the DSQ, a second validation study was performed, where 111 subjects undergoing anterior cervical spine surgery for degenerative disk disease completed the form preoperatively and at 4 weeks, 3 months, and 1 year after surgery. Results initially reported that the DSQ is considered a validated tool for the assessment of dysphagia in anterior cervical spine surgery patients.

Hurkmans, et al., (2012)'s experiment investigated whether or not modified diadochokinesis test has a strong internal consistency and adequate psychometric properties. Outlined results show that the test can be used to measure changes in speech motor control during treatment for apraxia of speech. Again, the aim of Marshall, et al., (2012)'s study was to in/validate a new technique designed for assessing and evaluating aphasics with different types of language deficits. The findings indicate a positive interaction and response to the new technique which conform its validity and reliability.

The validity and reliability of stroke aphasic depression questionnaire (SADQ) to assess aphasics of both sexes was also investigated. The new technique has been used to assess a165 aphasics of both sexes and is found to be a valid and reliable observational screening measure of depressive symptoms for stroke patients with aphasia (Cobley, et al., 2012). The researchers recommend the test, not only for aphasics, but also "for identifying patients who require further evaluation." (Cobley, et al., 2012: p.373)

Attard, et al., (2013) compare the validity and the reliability of two evaluative techniques, namely constraint-induced aphasia therapy-plus and multi-modality aphasia therapy to identify to what extent they assess aphasics' language abilities. The research team found that both techniques can be used as means of evaluating aphasics' linguistic abilities. Another experimental study examined reliability and validity of Dutch version of the life satisfaction questionnaire is undertaken by Boonstra, et al., (2012). The team used the test to assess 159 adult aphasics (over 18 years of age). Results of the team show that unlike the discriminate validity of the test which was good, the test's reliability was moderate. 
Aphasics' language-related functions and communication skills were assessed by trail making test. Allen, et al., (2012) who aim to measure the reliability and validity of the test, administered it for the first time to assess 242 aphasics (121 with sustained TBI and 121 normal control participants). Findings demonstrate that the comprehensive trail making test is sensitive to TBI and overall demonstrates classification rates that are comparable with some other versions of the test. In developing a test of language-related functions and communication skills for aphasics, the focus is usually on the reliability and validity of the test that will make the test usable. Examining the validity and reliability of the national institutes of health stroke scale, Okubo, et al, (2012) used the scale to assess 50 adult aphasics of both sexes (range 26-91 years). According to Okubo and his colleagues, the scale is highly sensitive (88\%) and specific (85\%) in detecting language impairments.

The study of von Steinbuechel, et al., (2012) employed the measures of global assessment to examine a 6-item QOLIBRI overall scale, and identify whether or not it could provide an index of HRQoL after traumatic brain injury (TBI). Seven hundreds and ninety-two subjects with TBI were included in the study, matched for age, education level and intelligence quotient (IQ), but not for language (6 different languages). Results show that the reliability of the QOLIBRI-OS was good and similar in participants with higher and lower cognitive performance. Factor analysis indicated that the scale is uni-dimensional. Additionally, the findings indicate a satisfactory fit with this model. The QOLIBRI-OS, according to the research analysis, correlates highly with the total score from the full QOLIBRI scale $(\mathrm{r}=0.87)$. Furthermore, moderate to strong relationships were found among the QOLIBRI-OS and the extended Glasgow outcome scale, short-form-36, and hospital anxiety and depression scale $(\mathrm{r}=0.54$ to -0.76$)$. Such outcomes demonstrate that the QOLIBRI-OS showed good construct validity in the TBI group. Functional connectivity stability was found in the results. These results underline the importance of the QOLIBRI-OS as a means through which clinicians, SLP/Ts and experts in the field can easily assesses a similar construct to the QOLIBRI total score and can be used as a brief index of HRQoL for TBI. Moreover, the study requires further investigation in larger and longitudinal studies.

Traditionally, validation research focusing on the brain included only one age group. Recently, inclusion of multiple -based group research has shown that significant differences in age groups contribute to unique profiles of cognitive, emotional, and neuropsychological dysfunction, as well as dimorphic patterns of structural brain damage and recovery. The study of Sadeq et al., (2013) employed ABR of 30 Arab infants with different auditory impairments and demographically-similar number of children participants to explore the validity and reliability of ABR to measure hearing problems in both Arab infants and children. Qualitative and statistical analyses revealed that ABR is valid and reliable when measuring Arab infants and children suffering from hearing problems.

\subsection{Aims of the Study}

Recent research indicates no differences in the results obtained from the analysis of CADL-2 pre-and-posttest when it was applied to test English gender aphasics, but little is known about the validity and reliability of the test when it is used to test Arabic aphasic patients of both 
sexes who are suffering from different types of language deficits. The current study used CADL-2 to determine whether or not it is valid and reliable. Specifically, we aim to find crucial answers for the following questions:

1. Can CADL-2 test what it was supposed to test?

2. Are the results obtained from the analysis of CADL-2 pre-and-posttest similar? To what extent these results are significantly the same/ different in light of gender differences?

\subsection{Methodology}

One of the two researchers took part in administering CADL-2 pre-and-posttest sessions to 100 gender aphasics (50 male and 50 females) who receive their therapeutic treatment at $\mathrm{Al}$ Khars hospital in Al Ahsa'a city, Kingdom of Saudi Arabia (KSA). The age of the participants ranges between 16 and 65 years old. The analysis was performed in several steps. The test was translated into Arabic language and Arabic translated version was standardized by three Arabic language specialists. The Arabic version of the CADL-2 was then presented in the first week as (a pre-test) to the participating aphasics who responded to the tester's questions and instructions. After 21 days ( 3 weeks), a second test (posttest) was given to the same participants. Examiner record booklets and patients' response booklets were then collected. The data were analyzed using qualitative and statistic content analyses. The researchers performed independent preliminary analyses, which were further developed and intensively discussed between them.

\section{Analysis}

\subsection{Validity of CADL-2 (Arabic version)}

\subsubsection{General Validity of CADL-2}

The past 5 years has seen a rapid expansion in the number of studies using new methods, strategies and/ or techniques to investigate maturational changes in the human brain. Designers of assessment tools, notably those of language tests like CADL-2 improved the test with the passage of time. Comprehensive targets almost covered all aspects of language activities. This can be clearly seen in the new version of CADL-2 which included all necessary categories mentioned in the first edition. Compare:

Table 1. CADL 1 and CADL-2: Comparison:

\begin{tabular}{|l|l|}
\hline CADL 1 categories (aspects) & CADL-2 categories (aspects) \\
\hline Role playing & \\
\hline Social convention & Social interaction \\
\hline Speech acts & Divergent communication \\
\hline Divergences & Contextual communication \\
\hline Utilize context & Sequential relationships \\
\hline Sequential relationships & Nonverbal communication \\
\hline Nonverbal/symbolic &
\end{tabular}




\begin{tabular}{|l|l|}
\hline Deixis & \\
\hline Reading, writing, and using numbers & Reading, writing, and using numbers \\
\hline Humor/ metaphor/ absurdity & Humor/metaphor/absurdity \\
\hline
\end{tabular}

As can be clearly seen, Table 1 illustrates how role playing is eliminated due to the unimportance it occupies when assessing aphasics' communicative activities. Clearly, role playing plays no pivotal role, especially when dealing with old patients with different types of language deficits. Social interaction covers all distinctive features of speech act along with social convention. The same thing applies to nonverbal communication which includes both nonverbal/ symbolic communication and deixis (time and place). Adding the term communication to the categories: divergence and utilize context gives an indication that the designers aim to use the term technically and functionally. Due to the ultimate importance of the language skills and language paralinguistic elements, the designers of CADL-2 keep them as they are in the second edition.

\subsubsection{Specific Validity of CADL-2}

In this section, the researchers reviewed the questions of CADL-2. The purpose was to prove that CADL-2 questions test what they are expected to test. This can be obviously seen in light of some random questions. Consider item 3 for example: دعنا نرى, أول إسمك هو (إسم خطأ) أليس ) (كنلك؟), 'let's see, your first name is (wrong name), isn't- it?' Evidently, the question prompts the patient to mouth up; therefore, it is consider as a challenge for Broca's aphasics, for example, who suffer from language production. A rapid view on the multiple choices given to the patient reveals that the designers of CADL-2 almost cover all alternatives anticipated about the type of selection the patient's response might fall into. Consider the three alternatives:

1 - (يتفق المريض مع الخطأ), 'The patient agrees with the miscommunication.' ( $0=$ Wrong answer).

2- يشير المريض إلى أن الإسم غير صحيح لكنه لا يصوّب الخطأ), 'The patient indicates that the name is incorrect but does not supply the correct name.' (1= Adequate answer).

3- (يصوّب المريض للمختبِر الإسم), 'The patient corrects the examiner.' (2= Correct answer).

Evidently, the designer nearly brings all probable choices the examinee (patient) may think of. In other words, the patient's answer will not be out of the above three mentioned choices.

One more example can be brought from item 20 where the examiner asks the patient to do something (perform an activity). Consider:

Examiner: (عبّئ هذه الإستمارة من فضلك), 'Please fill out this form.' Here the examiner examines the ability of the patient to write which means that the patient has to write. However, only those who are suffering from dysgraphia or agraphia will not be able to write and/ or compose. Such expectations are better in/validated with reference to the three alternative choices. Consider: 
1 - 'يكتب المريض باستخدام إصبعه/ها), 'The patient writes with his or her finger.' (0= Wrong answer).

2- المريض يشير بأنه/ها لا تستطيع ملئ الإستماره لكن لا يذكر لماذا) 'The patient indicates that he or she cannot fill out the form but does not indicate why.' (1= Adequate answer).

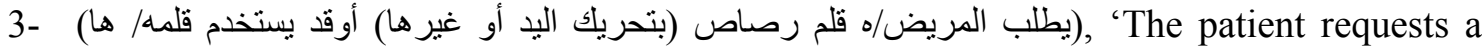
pencil (verbally or nonverbally) or gets his or her own.' ( 2 = Correct answer).

Obviously, the examiner does not leave any other choice for the examinee. Additionally, the question tests what is supposed to test (the linguistic and non-linguistic abilities of the aphasic).

\subsection{Reliability of CADLE-2 (Arabic version)}

\subsubsection{Pre-test}

The pre-test consists of forty-nine (49) questions. Designers of CADL-2 listed them as follows:

Item 1: (حيّي المريض بالقول أهلاً بالسيّد فُلان أوبالسيّدة فُلانه), 'Greet the patient by saying, “Hello, $\mathrm{Mr} / \mathrm{Ms}$ .."

Item 2: (ناولني القلم الرصاص لو سمحت), 'Would you mind hand me that pencil, please?"

Item 3: (دعنا نرى, أول إسمك هو (إسم خطأ) أليس كذلك؟)), 'Let's see, your first name is (wrong name), isn't-it?'

Item 4 : (أريد أن أفحص بعض المعلومات في سجلّك. هل عنو انك (عنوانٌ صحيح)?), 'I want to check some information in your chart. Is your address (correct address)?'

Item 5: (ما نوع العمل الذي كنت تعمله), 'What kind of work have you done?'

Item 6: (كيف حدث أن أُصبت بصعوبةُ في الكلام؟), 'How did your speech difficulty come about?'

Item 7: (ما أفضل وقتٍ هنا لتناول طعام الغداء؟), 'What's the best time here for eating lunch?'

Item 8: (هاك قائمة الطعام. جد قسم المأكو لات. ما الذي ترغب في أكله على وجبة الغداء؟), 'Here's a menu. Find the lunch section. What would you want for lunch?'

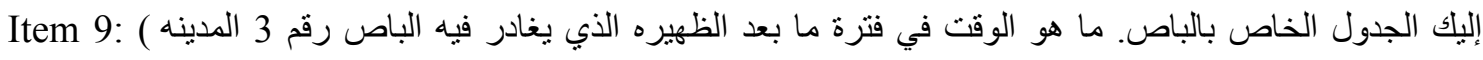
(الرئيسيه؟؟), 'Here is a bus schedule. What time in the afternoon does bus \#3 leave Maintwon?'

Item 10: (ما الذي يتوجّب عليك ارتداؤه أو استخدامه في يومٍٍ كهذا؟), What should you wear or use on a day like this?'

Item 11: (كيف تُشعر أحدهم أنك بارد), 'How would you let someone know that you're cold?'

Item 12: (أنظر إلى هذه الصور. أي واحدة منها تجدها مضحكه؟), 'Look at these pictures. Which one is funny?'

Item 13: (إليك دعوةٌ لحضور حفلة عيد ميلاد. حِددها في هذا التقويم), 'Here's an invitation to a birthday party. Mark it on this calendar.' 
Item 14: (إليك الساعه. إنها الآن تشير إلى الخمس الدقائق بعد العاشره)كم بقي على مو عدك؟), 'Here's the clock. It's now five minutes after ten. How long until your appointment?'

Item 15: (تفضّل الدليل الخاص بالعماره. أي طابق يوجد به مكتب السيد كلارك), “ Here is a building directory. What floor is Dr. Clark's office on?'

Item 16: (تذكّر أن مكتب الدكتور كلارك في الطابق الثالث وهذا هو المصعد فما الذي ستفعله بعد صعوده؟), 'Remember, Dr. Clark's office is on the third floor. Here's the elevator. What do you do after you step into the elevator?'

Item 17: (لنقل أنك دخلت غرفة الإنتظار بمكتب السيد كلارك ور أيت هذا. إلام توحي إليك هذه الإشاره فعله), 'Let's say that you walk into Dr. Clark's waiting room and see this. What does that sign tell you to do?'

Item 18: (لو سألتك موظفة الإستقبال “بم أخدمك ؟" بم كنت لتجيب؟), 'If the receptionist asked, 'May I help you?' what would you say?)

Item 19: (لو سألتك موظفة الإستقبال عن بعض وثائق الثبوتيه, فما الذي كنت ستُريها ؟), 'If the receptionist asked for some kind of identification, what would you show her?'

Item 20: (من فضلك عبّئ هذه الإستماره؟), 'Please fill out this form.'

Item 21: (المريض يعبّئ الإستماره), 'Patient fills out the form.'

Item 22: (كيف ستصف مشكلتاك للطبيب ؟), 'How would you describe your problem to the doctor?'

Item 23: (لوسألك الدكتور كلارك, "هل سبق وأن عانيت من الكلازموبسيا دوستونّبا؟" بم كنت ستُجيبه؟), 'If Dr. Clark asked you, 'Have you been experiencing Clasmopsia dotinnia?' what would you say?'

Item 24: (بحسب هذا الميسم, كم مقدار الأدويه الخاصة بالبرد يتوجّب عليك أخذها ؟), 'According to this label, how much cold medicine should you take?'

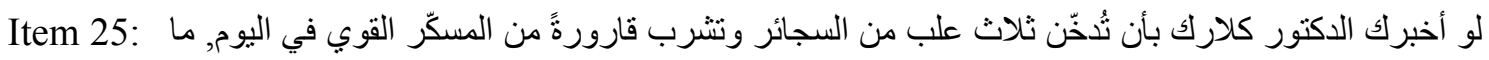
(كنت لتقول ؟), 'If Dr. Clark told you to smoke three packs of cigarettes and drink a bottle of gin a day, what would you say?'

Item 26: (لو احتجت إلى استخدام الحمّام, فأيّ واحدٍ كنت ستختار؟), 'If you needed to use the restroom, which one would you choose?'

Item 27: (أنرى هذه (صوره). ما الذي يجري), 'You see this. What's happening?'

Item 28: (ما الذي يتوجّب على السائق فعله؟), 'What should you the driver do?'

Item 29: (أيّ رمزٍ يصف هذه الصوره ؟), 'Which symbol describes this picture?'

Item 30: (أكتب قائمه لثلاثة أثشاء قد تحتاجها من البقاله؟), 'Make a list of three things you might need from the grocery store?'

Item 31: (تتوقف عند بقالةٍ لثر اء علبةٍ من حساء الطماطم. ما الذي ستختاره ؟), You stop a grocery store. You want to buy a can of tomato soup. Which will you pick?'

Item 32: (أيٌّ من هذه تتماشىى مع هذا الرمز؟), 'Which of these go with this symbol?' 
Item 33: (وهذ آلة بيع سفري. أرني كيف ستحصل على مشروب ؟), 'And here is a vending machine. Show me how you would get a drink?'

Item 34: (لو احتجت إلى الدواء, أبيّ نوع كنت لتشتريه بما تبقّى لديك من نقود؟ سعر كل واحدةٍ مذكورٌ هنا), 'If you needed medicine, which one could you buy with the money you have left? The price for each is listed here?'

Item 35: (إليك صورةً لمتجر. أين القسم الذي يمكنك أن تجد فيه دفتراً؟), 'Here is a picture of a store. Where's the section where you could find a notebook?'

Item 36: (تحتاج إلى أربطة حذاء, لكنك لا تسنطيع إيجادها. فلو أن البائع سألك: " أتريد خدم؟؟), 'You need shoelaces, but you can't find them. If a clerk asked, ‘ May I help you?' what would you say?'

Item 37: (تريد أربطة حذاء بيض- فقط أربطة حذاء بيضاء لاسواها. أين هي؟), You want white shoelacesonly white shoelaces. Where are they?'

Item 38: (إليك الخارطه. كيف بإمكانك الوصول من البنك إلى مكتب البريد ؟), 'Here's a map. How do you get from the bank to the post office?'

Item 39: (جد أين هي محلات إصلاح السيارات مدرجةً في هذه الصفحات الصفراء), 'Find where car repair shops are listed in these Yellow pages?'

Item 40: (جد الرقم (الخاص بأحد محلات إصلاح السيارات), 'Find the number.'

Item 41: (أماكن الإتصال (بمحلات إصلاح السيار ات), 'Places call.'

Item 42: (المريض يخبر المختبِ بالمعلومات السالفة الذكر؟), 'Reports to examiner?'

Item 43: (لو نظرت في الثارع ورأيت حريقاً. ما كنت ستفعل ؟), 'If you looked across the street and saw a fire, what would you do?'

Item 44: (لو اتصلت بـ911, ما الذي كنت ستخبر به عاملة الهاتف؟), 'If you called 911, what would you tell the operator?'

Item 45: (ما الذي يجري في هذه الصوره؟), 'What's happening in this picture?'

Item 46: (أي عنوانٍ في الصحيفه يتحدّث عما نراه في هذه الصوره ؟'), 'Which newspaper headline tells what you see in this picture?'

Item 47: (دوّنت شيئاً ما في التقويم منذ فترةٍ ليست بالبعيده. أيٌّ من هذه المدونات كان ذللك الثيئ المدوّن ؟), 'You scheduled something on the calendar a little time ago. Which one of these was it?'

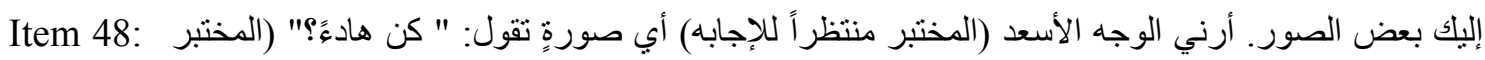

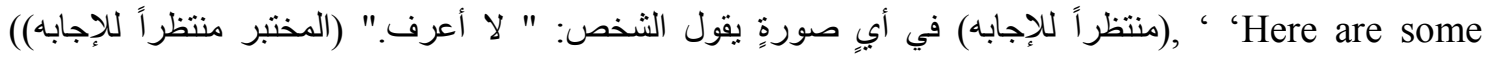
pictures. "Show me the happy face” Wait for response. "Which picture says, 'Be quiet"? Wait for response. "In which picture is the person saying, 'I don't know '?" Wait for response.'

Item 49: ("أرني الرسمة التي تتمانشى مع مقولة “ضرب السقف), 'Show me the drawing that goes with the saying "He hit the ceiling."

As it is clearly seen, the above mentioned questions address a number of linguistic and 
non-linguistic activities relating to aphasics. Functional activity is an important component of aphasic social life throughout his/ her life. Theoretical models and empirical data from psychoneurolinguistics, cognitive linguistics, and speech language therapy suggest that aphasics tend to do self-similar activities thy used to do before they become aphasic patients, and that such activities biases increase the adaptive value (e.g., self-relevance) of learned information. It is unclear, however, what neural mechanisms underlie people's tendency to perform certain activities be it linguistic tasks or non-linguistic challenges. Obviously, the above listed questions focused on the communication activities of daily living, a pervasive bias thought to be important for gender identity development. While undergoing CADL-2, participants found themselves face-to-face with their linguistic disabilities. Such challenge makes it easy for the researchers to identify which -ia each aphasic suffers from (e.g., dyslexia, dysgraphia, anomia, dyscalculia, etc.). Moreover, researchers have clearly identified how aphasics sign their language and/ or use meaningless hand signs when necessary. A statistical analysis of the participant's response demonstrated that the striatal region preferentially activated by language tasks is selectively activated by classical reward tasks in the literature. Taken together, these findings reveal a neurobiological mechanism associated with the type of aphasia and demonstrate a novel role of reward-processing neural structures in daily life's activities. However, such analysis can be clearly understood with reference to the participants' pre-test's scores that are listed in the following table. Consider:

Table 2. Participants' scores in CADL-2 pre-test

\begin{tabular}{|c|c|c|c|c|c|c|}
\hline $\begin{array}{c}\text { Participant's } \\
\text { Number }\end{array}$ & $\begin{array}{c}\text { Participant's } \\
\text { Name }\end{array}$ & Gender & Age & Raw Score & Percentile & $\begin{array}{c}\text { Stanine } \\
\text { Score }\end{array}$ \\
\hline 1 & Y A U & M & 64 & 44 & 10 & 2 \\
\hline 2 & A Y K & M & 59 & 90 & 89 & 7 \\
\hline 3 & S A Y & F & 37 & 3 & $<1$ & 1 \\
\hline 4 & S S A & M & 61 & 68 & 35 & 4 \\
\hline 5 & S I F & F & 60 & 78 & 55 & 5 \\
\hline 6 & S B K & F & 28 & 65 & 29 & 4 \\
\hline 7 & M S U & F & 37 & 98 & 99 & 9 \\
\hline 8 & M O D & M & 32 & 87 & 81 & 7 \\
\hline 9 & S M A & F & 61 & 56 & 20 & 3 \\
\hline 10 & F S C & F & 64 & 45 & 10 & 2 \\
\hline 11 & A S O & M & 59 & 12 & $<1$ & 1 \\
\hline 12 & Y M H & F & 52 & 34 & 5 & 2 \\
\hline 13 & A J A & M & 29 & 2 & $<1$ & 1 \\
\hline 14 & A G I & M & 25 & 76 & 51 & 5 \\
\hline 15 & A S E & M & 39 & 8 & $<1$ & 1 \\
\hline 16 & A A S & F & 63 & 9 & $<1$ & 1 \\
\hline 17 & H A W & F & 68 & 34 & 5 & 2 \\
\hline
\end{tabular}




\begin{tabular}{|c|c|c|c|c|c|c|}
\hline 18 & $\mathrm{FAS}$ & $\mathrm{M}$ & 17 & 98 & 99 & 9 \\
\hline 19 & H A A & $\mathrm{F}$ & 62 & 88 & 84 & 7 \\
\hline 20 & M A C & $\mathrm{M}$ & 29 & 67 & 32 & 4 \\
\hline 21 & $\mathrm{OM} \mathrm{C}$ & $\mathrm{M}$ & 17 & 58 & 21 & 3 \\
\hline 22 & A S O & $\mathrm{F}$ & 54 & 92 & 93 & 8 \\
\hline 23 & H S N & $\mathrm{M}$ & 56 & 19 & 1 & 1 \\
\hline 24 & A B H & $\mathrm{M}$ & 61 & 82 & 65 & 6 \\
\hline 25 & S H U & $\mathrm{F}$ & 64 & 73 & 45 & 5 \\
\hline 26 & M A N & $\mathrm{F}$ & 19 & 36 & 6 & 2 \\
\hline 27 & S B D & $\mathrm{M}$ & 47 & 36 & 6 & 2 \\
\hline 28 & A B R & $\mathrm{F}$ & 60 & 45 & 10 & 2 \\
\hline 29 & A B E & $\mathrm{M}$ & 45 & 54 & 19 & 3 \\
\hline 30 & N S D & $\mathrm{F}$ & 46 & 63 & 26 & 4 \\
\hline 31 & A S S & $\mathrm{M}$ & 43 & 73 & 45 & 5 \\
\hline 32 & N S P & $\mathrm{F}$ & 53 & 28 & 2 & 1 \\
\hline 33 & A S S & $\mathrm{M}$ & 25 & 91 & 90 & 8 \\
\hline 34 & A M S & $\mathrm{F}$ & 47 & 10 & $<1$ & 1 \\
\hline 35 & MA S & $\mathrm{M}$ & 31 & 19 & 1 & 1 \\
\hline 36 & A L & $\mathrm{M}$ & 48 & 92 & 93 & 8 \\
\hline 37 & A A S & $\mathrm{M}$ & 29 & 28 & 2 & 1 \\
\hline 38 & A M A & $\mathrm{M}$ & 53 & 83 & 67 & 6 \\
\hline 39 & K A & $\mathrm{M}$ & 27 & 47 & 11 & 2 \\
\hline 40 & $\mathrm{NA}$ & $\mathrm{F}$ & 25 & 64 & 27 & 4 \\
\hline 41 & S A S & $\mathrm{M}$ & 55 & 50 & 16 & 3 \\
\hline 42 & S A S & $\mathrm{M}$ & 57 & 11 & $<1$ & 1 \\
\hline 43 & M B A & $\mathrm{M}$ & 29 & 61 & 24 & 4 \\
\hline 44 & $\mathrm{AKA}$ & $\mathrm{F}$ & 49 & 60 & 23 & 3 \\
\hline 45 & A LA & $\mathrm{F}$ & 24 & 61 & 24 & 4 \\
\hline 46 & $\mathrm{~S} \mathrm{U}$ & $\mathrm{M}$ & 48 & 4 & $<1$ & 1 \\
\hline 47 & AAL & $\mathrm{M}$ & 50 & 8 & $<1$ & 1 \\
\hline 48 & A Y A & $\mathrm{F}$ & 26 & 61 & 24 & 4 \\
\hline 49 & A M A & $\mathrm{F}$ & 52 & 23 & 2 & 1 \\
\hline 50 & AAA & $\mathrm{F}$ & 54 & 55 & 20 & 3 \\
\hline 51 & A M J & $\mathrm{F}$ & 20 & 89 & 86 & 7 \\
\hline 52 & R GA & $\mathrm{F}$ & 63 & 88 & 84 & 7 \\
\hline 53 & A R & $\mathrm{F}$ & 64 & 45 & 10 & 2 \\
\hline 54 & H M & $\mathrm{F}$ & 21 & 33 & 4 & 1 \\
\hline 55 & B D A & $\mathrm{M}$ & 20 & 79 & 57 & 5 \\
\hline 56 & $\mathrm{PA}$ & $\mathrm{M}$ & 64 & 99 & $<99$ & 9 \\
\hline
\end{tabular}




\begin{tabular}{|c|c|c|c|c|c|c|}
\hline 57 & B R & M & 17 & 76 & 51 & 5 \\
\hline 58 & B R A & $F$ & 49 & 55 & 20 & 3 \\
\hline 59 & T R Q & $F$ & 59 & 28 & 2 & 1 \\
\hline 60 & T M H & $\mathrm{M}$ & 31 & 23 & 2 & 1 \\
\hline 61 & THA & $\mathrm{M}$ & 16 & 76 & 51 & 5 \\
\hline 62 & H D A & $\mathrm{M}$ & 65 & 89 & 86 & 7 \\
\hline 63 & SAS & $\mathrm{F}$ & 49 & 11 & $<1$ & 1 \\
\hline 64 & A D K & $\mathrm{F}$ & 19 & 4 & $<1$ & 1 \\
\hline 65 & S D Q & $\mathrm{F}$ & 48 & 5 & $<1$ & 1 \\
\hline 66 & $\mathrm{HNA}$ & $\mathrm{F}$ & 45 & 34 & 5 & 2 \\
\hline 67 & K M L & $\mathrm{F}$ & 34 & 65 & 29 & 4 \\
\hline 68 & H J R & $\mathrm{F}$ & 61 & 88 & 84 & 7 \\
\hline 69 & H M S & $\mathrm{F}$ & 65 & 56 & 20 & 3 \\
\hline 70 & R S D & $\mathrm{F}$ & 29 & 43 & 9 & 2 \\
\hline 71 & $\mathrm{OM}$ & $\mathrm{M}$ & 17 & 6 & $<1$ & 1 \\
\hline 72 & A S R & $\mathrm{M}$ & 64 & 77 & 54 & 5 \\
\hline 73 & A L I & $\mathrm{F}$ & 54 & 32 & 4 & 1 \\
\hline 74 & M H D & $\mathrm{M}$ & 33 & 45 & 10 & 2 \\
\hline 75 & M T H & M & 55 & 21 & 1 & 1 \\
\hline 76 & A Y M & $\mathrm{M}$ & 49 & 56 & 20 & 3 \\
\hline 77 & A D H & $\mathrm{M}$ & 47 & 43 & 9 & 2 \\
\hline 78 & AYH & $\mathrm{F}$ & 64 & 66 & 31 & 4 \\
\hline 79 & N R & $\mathrm{M}$ & 30 & 43 & 9 & 2 \\
\hline 80 & N J B & M & 22 & 12 & $<1$ & 1 \\
\hline 81 & T F Q & $\mathrm{M}$ & 20 & 78 & 55 & 5 \\
\hline 82 & R D A & $\mathrm{F}$ & 62 & 98 & 99 & 9 \\
\hline 83 & W F A & $\mathrm{F}$ & 38 & 78 & 55 & 5 \\
\hline 84 & W J D & M & 25 & 65 & 29 & 4 \\
\hline 85 & $\mathrm{HNA}$ & $\mathrm{F}$ & 19 & 56 & 20 & 3 \\
\hline 86 & S N S & $\mathrm{F}$ & 59 & 55 & 20 & 3 \\
\hline 87 & A S N & $\mathrm{F}$ & 44 & 43 & 9 & 2 \\
\hline 88 & AN S & M & 61 & 12 & $<1$ & 1 \\
\hline 89 & O M R & M & 65 & 69 & 38 & 4 \\
\hline 90 & A M J & $\mathrm{F}$ & 63 & 44 & 10 & 2 \\
\hline 91 & H S N & $\mathrm{M}$ & 17 & 31 & 3 & 1 \\
\hline 92 & A B J & M & 21 & 56 & 20 & 3 \\
\hline 93 & K L D & $\mathrm{F}$ & 18 & 72 & 43 & 5 \\
\hline 94 & S T N & $\mathrm{F}$ & 56 & 44 & 10 & 2 \\
\hline 95 & R H M & $\mathrm{F}$ & 23 & 78 & 55 & 5 \\
\hline
\end{tabular}




\begin{tabular}{|c|c|c|c|c|c|c|}
\hline 96 & A B L & M & 34 & 52 & 18 & 3 \\
\hline 97 & T M A & M & 17 & 33 & 4 & 1 \\
\hline 98 & N Q S & F & 60 & 89 & 86 & 7 \\
\hline 99 & N M Z & F & 45 & 33 & 4 & 1 \\
\hline 100 & N M H & M & 55 & 16 & $<1$ & 1 \\
\hline Total number of participants & \multicolumn{7}{|c|}{100 (50 males and 50 females) } \\
\hline \multicolumn{7}{|c|}{ Mean of ages } \\
Mean of raw scores
\end{tabular}

The qualitative discussion based on the statistical analysis is used in many studies to estimate volumes of anatomical structures in an unbiased fashion. Such procedure is a rapid, inexpensive approach that provides a correct outcome using outlined results obtained from the numbers. In Table 2, the researchers assessed the participants' communication activities of daily living. CADL-2 pre-test has been used here in light of age-sex-related changes. Forty nine (49) questions were asked by one of the researchers who followed the instructions of Cadl-2 examiner's manual. To estimate pre-test, it can be said that out of the one hundred participants whose mean of ages is 43.94, there was a marked improvement in males' performance with raw scores surging 2724 with a mean 54.48. On the other hand, aphasic females scored 2640 with a mean 52.8 which means that the functional communicative activity of aphasic males is higher than that of the aphasic females. Regardless the score achieved by both males and females, they both fall in the same percentile due to the fact that the mean for raw scores of both sexes is 53.64 which means that men's raw score as well as females' raw score is 28.83 on CADL-2 percentile. The same thing applies to CADL-2 Stanine scores where both males and females fall in the slot 3.38 .

\subsubsection{Posttest}

Posttest is administered at the end of the third week. The purpose was to compare the participant's performance with that of the pre-test. Strictly, information listed in Table 2 becomes clearer in view of CADL-2 posttest illustrated in the following table. Consider:

Table 3. CADL-2 posttest: Performance of aphasic participants

\begin{tabular}{|c|c|c|c|c|c|c|}
\hline $\begin{array}{c}\text { Participant's } \\
\text { Number }\end{array}$ & $\begin{array}{c}\text { Participant's } \\
\text { Name }\end{array}$ & Gender & Age & Raw Score & Percentile & $\begin{array}{c}\text { Stanine } \\
\text { Score }\end{array}$ \\
\hline 1 & Y A U & M & 64 & 47 & 11 & 2 \\
\hline 2 & A Y K & M & 59 & 95 & 96 & 8 \\
\hline 3 & S A Y & F & 37 & 4 & $<1$ & 1 \\
\hline 4 & S S A & M & 61 & 64 & 27 & 4 \\
\hline 5 & S I F & F & 60 & 82 & 65 & 6 \\
\hline 6 & S B K & F & 28 & 61 & 24 & 4 \\
\hline
\end{tabular}




\begin{tabular}{|c|c|c|c|c|c|c|}
\hline 7 & M S U & $\mathrm{F}$ & 37 & 97 & 98 & 9 \\
\hline 8 & M O D & $\mathrm{M}$ & 32 & 89 & 86 & 7 \\
\hline 9 & S M A & $\mathrm{F}$ & 61 & 60 & 23 & 3 \\
\hline 10 & F S C & $\mathrm{F}$ & 64 & 41 & 9 & 2 \\
\hline 11 & A S O & $\mathrm{M}$ & 59 & 13 & $<1$ & 1 \\
\hline 12 & Y M H & $\mathrm{F}$ & 52 & 31 & 3 & 1 \\
\hline 13 & A J A & $\mathrm{M}$ & 29 & 4 & $<1$ & 1 \\
\hline 14 & A G I & $\mathrm{M}$ & 25 & 77 & 54 & 5 \\
\hline 15 & A S E & $\mathrm{M}$ & 39 & 5 & $<1$ & 1 \\
\hline 16 & A A S & $\mathrm{F}$ & 63 & 11 & $<1$ & 1 \\
\hline 17 & H A W & $\mathrm{F}$ & 68 & 38 & 7 & 2 \\
\hline 18 & F A S & $\mathrm{M}$ & 17 & 99 & $>99$ & 9 \\
\hline 19 & H A A & $\mathrm{F}$ & 62 & 89 & 86 & 7 \\
\hline 20 & M A C & $\mathrm{M}$ & 29 & 65 & 29 & 4 \\
\hline 21 & $\mathrm{OM} \mathrm{C}$ & $\mathrm{M}$ & 17 & 59 & 22 & 3 \\
\hline 22 & A S O & $\mathrm{F}$ & 54 & 90 & 89 & 7 \\
\hline 23 & H S N & $\mathrm{M}$ & 56 & 21 & 1 & 1 \\
\hline 24 & A B H & $\mathrm{M}$ & 61 & 80 & 60 & 5 \\
\hline 25 & S H U & $\mathrm{F}$ & 64 & 73 & 45 & 5 \\
\hline 26 & M A N & $\mathrm{F}$ & 19 & 39 & 8 & 2 \\
\hline 27 & S B D & $\mathrm{M}$ & 47 & 34 & 5 & 2 \\
\hline 28 & A B R & $\mathrm{F}$ & 60 & 42 & 9 & 2 \\
\hline 29 & A B E & $\mathrm{M}$ & 45 & 50 & 16 & 3 \\
\hline 30 & N S D & $\mathrm{F}$ & 46 & 61 & 24 & 4 \\
\hline 31 & A S S & $\mathrm{M}$ & 43 & 73 & 45 & 5 \\
\hline 32 & N S P & $\mathrm{F}$ & 53 & 25 & 2 & 1 \\
\hline 33 & A S S & $\mathrm{M}$ & 25 & 90 & 89 & 7 \\
\hline 34 & AMS & $\mathrm{F}$ & 47 & 11 & $<1$ & 1 \\
\hline 35 & MAS & $\mathrm{M}$ & 31 & 19 & 1 & 1 \\
\hline 36 & A L & $\mathrm{M}$ & 48 & 91 & 90 & 8 \\
\hline 37 & AAS & $\mathrm{M}$ & 29 & 32 & 4 & 1 \\
\hline 38 & A M A & $\mathrm{M}$ & 53 & 85 & 77 & 6 \\
\hline 39 & K A & $\mathrm{M}$ & 27 & 49 & 14 & 3 \\
\hline 40 & NA & $\mathrm{F}$ & 25 & 66 & 31 & 4 \\
\hline 41 & SAS & $\mathrm{M}$ & 55 & 54 & 19 & 3 \\
\hline 42 & SAS & $\mathrm{M}$ & 57 & 8 & $<1$ & 1 \\
\hline 43 & M B A & $\mathrm{M}$ & 29 & 66 & 31 & 4 \\
\hline 44 & A KA & $\mathrm{F}$ & 49 & 56 & 20 & 3 \\
\hline 45 & A L A & $\mathrm{F}$ & 24 & 68 & 35 & 4 \\
\hline
\end{tabular}




\begin{tabular}{|c|c|c|c|c|c|c|}
\hline 46 & $\mathrm{~S} \mathrm{U}$ & $\mathrm{M}$ & 48 & 1 & $<1$ & 1 \\
\hline 47 & A A L & $\mathrm{M}$ & 50 & 5 & $<1$ & 1 \\
\hline 48 & A Y A & $\mathrm{F}$ & 26 & 70 & 40 & 4 \\
\hline 49 & A M A & $\mathrm{F}$ & 52 & 18 & $<1$ & 1 \\
\hline 50 & A AA & $\mathrm{F}$ & 54 & 55 & 20 & 3 \\
\hline 51 & A M J & $\mathrm{F}$ & 20 & 79 & 57 & 5 \\
\hline 52 & R G A & $\mathrm{F}$ & 63 & 89 & 86 & 7 \\
\hline 53 & A R & $\mathrm{F}$ & 64 & 49 & 14 & 3 \\
\hline 54 & $\mathrm{H} \mathrm{M}$ & $\mathrm{F}$ & 21 & 37 & 7 & 2 \\
\hline 55 & B D A & $\mathrm{M}$ & 20 & 78 & 55 & 5 \\
\hline 56 & PA & $\mathrm{M}$ & 64 & 97 & 98 & 9 \\
\hline 57 & B R & $\mathrm{M}$ & 17 & 68 & 35 & 4 \\
\hline 58 & B R A & $\mathrm{F}$ & 49 & 60 & 23 & 3 \\
\hline 59 & T R Q & $\mathrm{F}$ & 59 & 24 & 2 & 1 \\
\hline 60 & T M H & $\mathrm{M}$ & 31 & 20 & 1 & 1 \\
\hline 61 & T H A & $\mathrm{M}$ & 16 & 70 & 40 & 4 \\
\hline 62 & H D A & $\mathrm{M}$ & 65 & 84 & 72 & 6 \\
\hline 63 & S A S & $\mathrm{F}$ & 49 & 7 & $<1$ & 1 \\
\hline 64 & A D K & $\mathrm{F}$ & 19 & 4 & $<1$ & 1 \\
\hline 65 & S D Q & $\mathrm{F}$ & 48 & 7 & $<1$ & 1 \\
\hline 66 & H N A & $\mathrm{F}$ & 45 & 40 & 8 & 2 \\
\hline 67 & K M L & $\mathrm{F}$ & 34 & 71 & 41 & 5 \\
\hline 68 & H J R & $\mathrm{F}$ & 61 & 81 & 62 & 6 \\
\hline 69 & H M S & $\mathrm{F}$ & 65 & 44 & 10 & 2 \\
\hline 70 & R S D & $\mathrm{F}$ & 29 & 54 & 19 & 3 \\
\hline 71 & $\mathrm{OM}$ & $\mathrm{M}$ & 17 & 9 & $<1$ & 1 \\
\hline 72 & A S R & $\mathrm{M}$ & 64 & 67 & 32 & 4 \\
\hline 73 & A L I & $\mathrm{F}$ & 54 & 38 & 7 & 2 \\
\hline 74 & M H D & $\mathrm{M}$ & 33 & 54 & 19 & 3 \\
\hline 75 & M T H & $\mathrm{M}$ & 55 & 23 & 2 & 1 \\
\hline 76 & AYM & $\mathrm{M}$ & 49 & 49 & 14 & 3 \\
\hline 77 & A D H & $\mathrm{M}$ & 47 & 43 & 9 & 2 \\
\hline 78 & A Y H & $\mathrm{F}$ & 64 & 69 & 38 & 4 \\
\hline 79 & $\mathrm{NR}$ & $\mathrm{M}$ & 30 & 43 & 9 & 2 \\
\hline 80 & N J B & $\mathrm{M}$ & 22 & 17 & $<1$ & 1 \\
\hline 81 & T F Q & $\mathrm{M}$ & 20 & 79 & 57 & 5 \\
\hline 82 & R D A & $\mathrm{F}$ & 62 & 98 & 99 & 9 \\
\hline 83 & W F A & $\mathrm{F}$ & 38 & 78 & 55 & 5 \\
\hline 84 & W J D & $\mathrm{M}$ & 25 & 65 & 29 & 4 \\
\hline
\end{tabular}




\begin{tabular}{|c|c|c|c|c|c|c|}
\hline 85 & H N A & $\mathrm{F}$ & 19 & 60 & 23 & 3 \\
\hline 86 & S N S & $\mathrm{F}$ & 59 & 60 & 23 & 3 \\
\hline 87 & A S N & $\mathrm{F}$ & 44 & 41 & 9 & 2 \\
\hline 88 & A N S & M & 61 & 22 & 2 & 1 \\
\hline 89 & O M R & $\mathrm{M}$ & 65 & 76 & 51 & 5 \\
\hline 90 & A M J & $\mathrm{F}$ & 63 & 47 & 11 & 2 \\
\hline 91 & H S N & $\mathrm{M}$ & 17 & 26 & 2 & 1 \\
\hline 92 & A B J & $\mathrm{M}$ & 21 & 43 & 9 & 2 \\
\hline 93 & K L D & $\mathrm{F}$ & 18 & 66 & 31 & 4 \\
\hline 94 & $\mathrm{~S} T \mathrm{~N}$ & $\mathrm{~F}$ & 56 & 41 & 9 & 2 \\
\hline 95 & R H M & $\mathrm{F}$ & 23 & 85 & 77 & 6 \\
\hline 96 & A B L & $\mathrm{M}$ & 34 & 42 & 9 & 2 \\
\hline 97 & T MA & $\mathrm{M}$ & 17 & 38 & 7 & 2 \\
\hline 98 & NQ S & $\mathrm{F}$ & 60 & 89 & 86 & 7 \\
\hline 99 & N M Z & $\mathrm{F}$ & 45 & 33 & 4 & 1 \\
\hline 100 & $\mathrm{NMH}$ & $\mathrm{M}$ & 55 & 21 & 1 & 1 \\
\hline \multicolumn{2}{|c|}{ Total number of participants } & \multicolumn{5}{|c|}{100 (50 males and 50 females) } \\
\hline \multicolumn{2}{|c|}{ Mean of ages } & \multicolumn{5}{|c|}{43.94} \\
\hline \multicolumn{2}{|c|}{ Mean of raw scores } & \multicolumn{5}{|c|}{48.78} \\
\hline \multicolumn{2}{|c|}{ Mean of CADL-2 percentiles } & \multicolumn{5}{|c|}{28.69} \\
\hline \multicolumn{2}{|c|}{$\begin{array}{c}\text { Mean of CADL-2 Stanine } \\
\text { score }\end{array}$} & \multicolumn{5}{|c|}{3.37} \\
\hline
\end{tabular}

In Table 3, it was found that significant decreases in the performance of males in comparison to their performance in the pre-test (2509 vs. 2724 , accordingly). Such remarkable decrease does not emerge as a result of increasing age, because the time between the two tests (pre-and-posttest) is limited (one week). This remarkable alteration can be clearly observed in view of the mean of raw scores for both males and females (50.18 vs. 52 . 18, respectively). Likewise, the mean of CADL-2 percentiles and Stanine score in both tests is not different (28.83, 28. 69, 3.38 and 3.37 accordingly). The legitimate question that poses itself is the following: Does such significant differences affect the general evaluation of both men and women at hand? Furthermore, does this result affect the validity of CADL-2 in general and reliability of the test in particular? To address these questions, one needs to go back to the percentiles of CADL-2 where we find that both raw scores of pre-and-posttests fall in the same percentile category (24-40). Therefore, the two percentile scores of the two tests (pre-and-posttest) in addition to the Stanine scores of them are the same which undoubtedly means that CADL-2 is both valid and reliable.

\section{Conclusion}

While the importance of assessing aphasics' communication activities of daily living is increasingly underscored by recent literature, conventional assessment tools and evaluative language tests obscure potentially important regional variations in the speech language 
therapy. The objective of this study was to measure the validity and reliability of CADL-2 when using the test as an assessment tool to assess aphasics' functional communicative activities. It is seen how qualitative and statistical analyses are able to identify the validity and reliability of CADL-2. For the validity of CADL-2, it is found that the questions of the test were carefully designed for assessing different types of aphasia that gender adult aphasics normally suffer from. Alternative choices describing the response of aphasics (raw scores) were calculated and analyzed in decided to the examiner's manual. Clearly, each alternative choice presented a precise diagnosis of the type of aphasia gender participants suffer from. Aphasia's assessment criteria describing the communication activities of daily living distribution were estimated using practical analysis evaluated and analyzed by the designers of ACDL-2. Questions of the test were defined based on the functional activities to quantify regional parameter variation. Subjects were categorized by gender, and age for analysis. To guarantee the validity of the test, the researchers followed the instructions and guidelines in the attached booklets of CADL-2 step by step. In general, the responses of the participants in hand showed no significant variations in the pre-test as compared with the posttest which demonstrate that they tested what they were expected or supposed to test. Again, this indicates that the test is valid.

At both tests (pre-and-posttest) participants' performance (with respect to raw scores' distribution) provided evidence of the reliability of CADL-2. Comparing women to men, unimportant differences in the mean of raw scores, percentiles and Stanine scores were most pronounced and observed in both tests. Compare:

Table 4. Gender's scores: Comparison

\begin{tabular}{|c|c|c|c|c|}
\hline \multirow{2}{*}{ Items } & \multicolumn{2}{|c|}{ Pre-test } & \multicolumn{2}{|c|}{ Posttest } \\
\cline { 2 - 5 } & Males & Females & Males & Females \\
\hline Raw scores & 2724 & 2640 & 2505 & 2639 \\
\hline Mean of raw scores & 43.94 & 52.8 & 50.1 & 52.78 \\
\hline $\begin{array}{c}\text { Mean of CADL-2 } \\
\text { Percentile }\end{array}$ & 29.5 & 28.16 & 28.6 & 28.78 \\
\hline $\begin{array}{c}\text { Mean of CADL-2 } \\
\text { Stanine scores }\end{array}$ & 3.4 & 3.38 & 3.32 & 3.38 \\
\hline
\end{tabular}

Table 4 explains in details the mean of percentages for raw scores, CADL-2 percentiles, and CADL-2 Stanine scores of both males and females. Regardless the differences that one can easily observe, it can be said that such percentages do not affect the general results of the participants' performance in both tests. Figures 1 and 2 below summarize the outcomes. Compare: 




Figure 1. Pre-test general outcomes

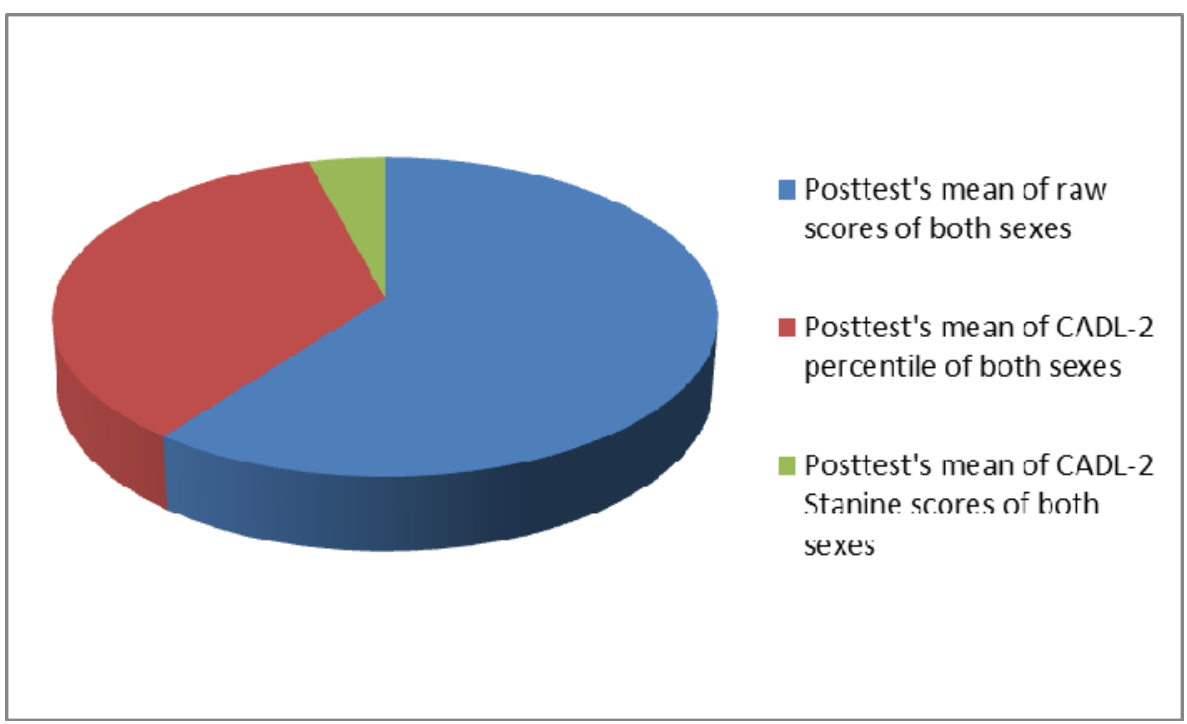

Figure 2. Posttest general outcomes

Comparing pre-test (Figure 1) to posttest (Figure 2), no significant differences were pronounced between the two. This is strong evidence that the two tests are similar if not almost the same which indicate that the CADL-2 is reliable. Note here that the level of the communication activities is, according to CADL-2 criteria is low. These results suggest that CADL-2 is important in studies of communication activities of daily living and assessment effects, particularly where participants are adult aphasics of both sexes. Therefore, the researchers recommend it for assessing such functional communicative activities in Arab aphasics. A better understanding of the processes of scores' interpretation may help to distinguish the functional activities of adult aphasics of both sexes. 


\section{References}

Allen, D., Thaler, N., Barchard, K., Vertinski, M., \& Mayfield, J. (2012). Factor structure of the Comprehensive Trail Making Test in children and adolescents with brain dysfunction. Psychological Assessment, 24(4), 964-972. http://dx.doi.org10.1037/a0028521.

Al-Yaari, S., \& Almaflehi, N. (2013). Effects of Auditory Brainstem Response (ABR) on Measuring Children's Auditory Functions: An Experimental Investigation . In press, 1-17.

Attard, M., Rose, M. L., \& Lanyon, L. (2013). The comparative effects of Multi-Modality Aphasia Therapy and Constraint-Induced Aphasia Therapy-Plus for severe chronic Broca's aphasia: An in-depth pilot study. Aphasiology, 27(1), 80-111. http://dx.doi.org10.1080/02687038.2012.725242.

Below, J. L., Skinner, C. H., Fearrington, J. Y., \& Sorrell, C. A. (2010). Gender Differences in Early Literacy: Analysis of Kindergarten through Fifth-Grade Dynamic Indicators of Basic Early Literacy Skills Probes. School Psychology Review, 39(2), 240-257.

Block, K., Amie, A., Chery, J., Gina, N., Peggy, A., Deborah, W., \& Sara, H. (1993). "Definitions of Communication Disorders and Variations", Ad Hoc Committee on Service Delivery in the Schools. ASHA, 13-14. http://dx.doi.org10.1044/policy. RP1993-00208, retrieved 2010-08-07.

Boonstra, A., Reneman, M., Stewart, R., \& Balk, G. (2012). Life satisfaction questionnaire (Lisat-9): reliability and validity for patients with acquired brain injury. International Journal Of Rehabilitation Research, 35(2), 153-160.

Brogden, L. (2008). Language and gender: An advanced resource book. Canadian Journal Of Applied Linguistics, 11(2), 121-123.

Cobley, C., Thomas, S., Lincoln, N., \& Walker, M. (2012). The assessment of low mood in stroke patients with aphasia: reliability and validity of the 10-item Hospital version of the Stroke Aphasic Depression Questionnaire (SADQH-10). Clinical Rehabilitation, 26(4), 372-381. http://dx.doi.org10.1177/0269215511422388.

Eggermont, J. J., Burkard, R. F., \& Manuel, D. (2007). Auditory evoked potentials: basic principles and clinical application. Hagerstwon, MD: Lippincott Williams \& Wilkins, p. 3. ISBN 0-7817-5756-8. OCLC 70051359.

Hurkmans, J., Jonkers, R., Boonstra, A. M., Stewart, R. E., \& Reinders-Messelink, H. A. (2012). Assessing the treatment effects in apraxia of speech: introduction and evaluation of the Modified Diadochokinesis Test. International Journal Of Language \& Communication Disorders, 47(4), 427-436. http://dx.doi.org 10.1111-1460-6984. 2012.00155x.

Marshall, J., Best, W., Cocks, N., Cruice, M., Pring, T., Bulcock, G., \& Cautea, A. (2012). Gesture and Naming Therapy for People With Severe Aphasia: A Group Study. Journal Of Speech, Language \& Hearing Research, 55(3), 726-738. http://dx.doi.org10.1044/1092-4388(20122)/11-0219. 
Marshall, N., Herens, J., \& Goldstein, C. (2011). Mothers and Their Retarded Children VS Mothers and Their Nonretarded Children. Am. J. Mental Def., 415-419.

Neisser, U. (1997). "Rising Scores on Intelligence Tests". American Scientist, 85, 440-447.

Okubo, P., Fábio, S., Domenis, D., \& Takayanagui, O. (2012). Using the National Institute of Health Stroke Scale to predict dysphagia in acute ischemic stroke. Cerebrovascular Diseases (Basel, Switzerland), 33(6), 501-507. http://dx.doi.org10.1159/000336240.

Philibert, B., Durrant, J., Ferber-Viart, C., Duclaux, R., Veuillet, E., \& Collet, L. (2003). Stacked tone-burst-evoked auditory brainstem response (ABR): preliminary findings. International Journal Of Audiology, 42(2), 71-81.

Rehman, T., Ali, R., \& Yonas, H. (2008). "Rapid progression of traumatic bifrontal contusions to transtentorial herniation: A case report. Cases Journal, 1-7.

Skeppholm, M., Ingebro, C., Engström, T., \& Olerud, C. (2012). The Dysphagia Short Questionnaire: an instrument for evaluation of dysphagia: a validation study with 12 months' follow-up after anterior cervical spine surgery. Spine [Spine (Phila Pa 1976)] 2012 May 15; Vol. 37(11), pp. 996-1002. http://dx.doi.org 10.1097/BRS.0b013e31823a7a5b.

Sutcliffe, L., \& Lincoln, N. (1998 Dec;12(6)). The assessment of depression in aphasic stroke patients: the development of the Stroke Aphasic Depression Questionnaire. Clin Rehabil, 506-13.

von-Steinbuechel, N., Wilson, L., Gibbons, H., Muehlan, H., Schmidt, H., Schmidt, S., .. . Zitnay, G. (2012). QOLIBRI overall scale: a brief index of health-related quality of life after traumatic brain injury. Journal Of Neurology, Neurosurgery, And Psychiatry [J Neurol Neurosurg Psychiatry] 2012 Nov; Vol. 83 (11), pp. 1041-7.

\section{Glossary}

ABR (Auditory Brainstem Response) It is a neurologic test of auditory brainstem function in response to auditory (click) stimuli. First described by Jewett and Williston in 1971, ABR audiometry is the most common application of auditory evoked responses. The resulting recording is a series of vertex positive waves of which I through $\mathrm{V}$ are evaluated. These waves, labeled with roman numerals in Jewett and Williston convention, occur in the first 10 milliseconds after onset of an auditory stimulus. ABR is a helpful tool in determining a child's ability to hear. The test uses a special computer to measure the way the child's hearing nerve responds to different sounds (Eggermont, et al., 2007: p. 3).

CADL-2 (Communication Activities of Daily Living, Second Edition) The test assesses the functional communication skills of adults with neurogenic communication disorders. The CADL-2 is given individually in about 30 minutes and contains 50 test items that assess communication activities in seven areas: Reading, writing, and using numbers; Social interaction; Divergent communication; Contextual communication; Nonverbal communication; Sequential relationships; and Humor/metaphor/absurdity. Original CADL 
items that required role playing, use of an audiocassette for identification of environmental sounds, and certain props were eliminated to ease test administration and reduce total test time.

The updated norming sample included 175 adults with neurogenic communication disorders resulting primarily from left- or right-hemisphere stroke or traumatic brain injury. Level of care spanned the full continuum of acute care to sub-acute, long-term, home, and outpatient care. The sample was stratified to approximate the 1997Statistical Abstract of the United States (U.S. Bureau of the Census). Reliability coefficients were: .93 coefficient alpha, .85 test-retest, and .99 inter-scorer. The CADL-2 also was found to be valid as a functional communication test for adult neurogenic populations. Complete CADL-2 Kit includes: Examiner's Manual, Picture Book, 25 Examiner Record Booklets, and 25 Patient Response Forms, all in a sturdy storage box (http://www.proedinc.com/ customer/ ProductView.aspx?ID=1533\&sSearchWord=).

DSQ (Dysphagia Short Questionnaire) This questionnaire is considered to be a validated tool for the assessment of dysphagia in anterior cervical spine surgery patients (Skeppholm, et al., 2012: pp.996-1002).

IQ (intelligence quotient) It is a score derived from one of several standardized tests designed to assess intelligence. The abbreviation "IQ" comes from the German term Intelligenz-Quotient, originally coined by psychologist William Stern. When modern IQ tests are devised, the mean (average) score within an age group is set to 100 and the standard deviation (SD) almost always to 15 ( Neisser, 1997: pp. 440-447).

QOLIBRI (Quality of Life after Brain Injury) is the first instrument specifically developed to assess health-related quality of life (HRQoL) of individuals after traumatic brain injury. Disease or condition-specific HRQoL instruments are assumed to be more sensitive to particular health conditions and therefore give more focused and more precise information than generic ones (http://www.qolibrinet.com/).

SADQ (Stroke Aphasic Depression Questionnaire) This questionnaire was developed to assess the depression in aphasic stroke patients. It is a 21-item questionnaire developed based on observable behaviors thought to be associated with depressed mood. It is completed by the client's caregiver on behalf of the client (Sutcliffe \& Lincoln, 1998: pp. 506-513).

SLP/Ts (Speech-Language Pathologists/ Therapists) They are specialized in communication disorders as well as swallowing disorders. They are also called Speech Pathologists (Block et al., 1993: p. 23)

TBI (Traumatic Brain Injury) It occurs when an external force traumatically injures the brain. TBI can result when the head suddenly and violently hits an object, or when an object pierces the skull and enters brain tissue (Rehman et al., 2008: pp.1-7). 


\section{Copyright Disclaimer}

Copyright reserved by the author(s).

This article is an open-access article distributed under the terms and conditions of the Creative Commons Attribution license (http://creativecommons.org/licenses/by/3.0/). 